Se prohíbe su reproducción total o parcial por cualquier medio, incluido electrónico, sin permiso previo y por escrito de los editores.

\title{
DOSSIER
}

\author{
HOMENAJE A \\ NORA PASTERNAC
}


Se prohíbe su reproducción total o parcial por cualquier medio, incluido electrónico, sin permiso previo y por escrito de los editores. 


\section{CONTRIBUCIONES \\ DE NORA PASTERNAC EN ESTUDIOS}

Estudios se honra en ofrecer esta pequeña muestra de gratitud a la labor académica y administrativa que la doctora Nora Pasternac ha llevado a cabo en nuestra revista con tanto profesionalismo y entusiasmo por treinta años.

Enumeramos a continuación sus contribuciones propias y traducciones en nuestra revista:

- "Literatura gauchesca y parodia: el fausto criollo", Estudios 102 (2012), pp. 61-78.

- “Una ginebra desastrosa”, Estudios 93 (2010), pp. 169-178.

- "Silvina Bullrich: 'ese animal no existe"”, Estudios 87 (2008), pp. 131-141.

- "La aventura y el orden: la vanguardia y la revista Sur", Estudios 78 (2006), pp. 125-135.

- "La revista Sur y el exilio literario español”, Estudios 72 (2005), pp. 7-19.

- "Internet frente a la escritura", Estudios 66 (2003), pp. 128-133.

- "Jorge Luis Borges en la revista Sur: un episodio de la historia literaria", Estudios 60-61 (2000), pp. 47-71.

- "Eduardo Mallea: escritura, mito y solemnidad", Estudios 47 (1996-1997), pp. 71-85.

- "Exégesis de un poema de Mallarmé", Émile Noulet, traducción de Nora Pasternac, Estudios 41 (1995), pp. 95-99. 
DOSSIER

- "Reflexiones sobre la traducción y sus traiciones”, Estudios 37 (1994), pp. 85-91.

- “José Saramago, historia del cerco de Lisboa”, Estudios 35 (19931994), pp. 109-110.

- "El anticervantismo de Borges: de Paul Groussac a Pierre Menard", Estudios 31 (1992-1993), pp. 51-66.

- "Ramón Fernández, escritor y colaboracionista”, Estudios 29 (1992), pp. 71-83.

- "La plaza fuerte de las revistas", Jean Pierrard, traducción de Nora Pasternac, Estudios 19-20 (1989-1990), pp. 189-192.

- "El liberalismo norteamericano y sus críticos: Rawls, Taylor, Sandel, Walzer”, Chantal Mouffe, traducción de Nora Pasternac, Estudios 15 (1988), pp. 95-114.

Gracias, querida Nora, por contribuir a la calidad académica de Estudios durante todo este tiempo.

Carlos Gutiérrez Lozano

Director 